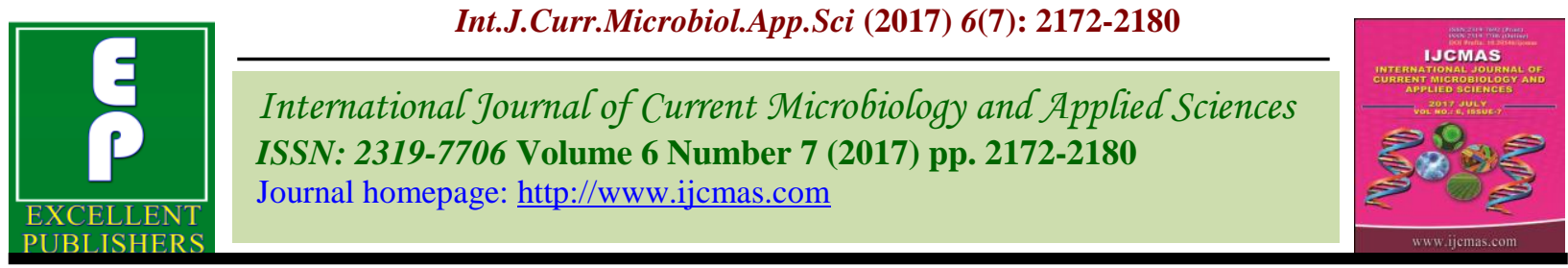

Original Research Article

https://doi.org/10.20546/ijcmas.2017.607.255

\title{
Production and Profitability Analysis of Grapevine Orchard in Coimbatore, Tamil Nadu, India
}

\author{
S. Appasmandri ${ }^{1 *}$, M. Anjugam², M. Sathaiah ${ }^{2}$ and B. Muthuraja ${ }^{3}$ \\ ${ }^{1}$ Faculty of Agriculture and Animal Husbandry, Gandhigram Rural Institute-Deemed University, \\ Dindigul, Tamil Nadu, India \\ ${ }^{2}$ Department of Agricultural Economics, Center for Agriculture and Rural Development Studies, \\ Tamil Nadu Agricultural University, Coimbatore- 641003, Tamil Nadu, India \\ ${ }^{3}$ Ramakrishna Mission Vivekananda University, Coimbatore- 641020, Tamil Nadu, India \\ *Corresponding author
}

A B S T R A C T

The economic analysis, production and profitability of grapevine orchard in Coimbatore district of Tamil Nadu was performed. Present study revealed that an Keywords

Grape,

Profitability, Cost benefit analysis, Resource use efficiency.

Article Info

Accepted:

21 June 2017 Available Online: 10 July 2017 area under grape cultivation is decreasing over a decade by 1.17 per cent. Similarly, production and productivity also declined by 10.16 and 9.55 per cent respectively. The factors which are significantly positively influence the yield of grapes are age of vine yard, application of farmyard manure and phosphorus. Annual establishment cost was worked out to be Rs. 4.25 lakhs per ha. Establishment of grape enterprise was found to be financially feasible and net return was high which is about Rs. 2.13 lakhs per ha. It was observed from the study that lack of price information (score I) and disease infestation (score II) were the major constraints to inhibit grapevine cultivation. Providing current price information, assistance in exporting, developing new high yielding variety, resistant to disease infestation and tolerant to climatic condition and proper harmonization of Grape Growers Association may increase the welfare of the growers.

\section{Introduction}

Cultivation of fruit crops plasys a vital role in the agricultural development of a nation. It is stated that the standard of living of the people of a country can be judged by its production and consumption of fruit per capita. Fruits are the chief source of vitamins and minerals, without which human body cannot maintain proper health and resistance to disease. Globally, Spain is a leading country in terms of area under fruits with of 9.44 lakhs ha (13\%) and China is a major producer with
116.50 tones $(15 \%)$ during the year 2013. In terms of productivity, India rank first with 21.80 tones/ha. In India, grape is cultivated in an area of 1.11 lakh ha with an annual production of 25.85 lakh tones during 201314. Maharashtra ranks first in terms of area under grape (90000 ha) accounted for a major share of $76 \%$ followed by Karnataka grown in 20500 ha (17\%) and Tamil Nadu growing grapes under 2800 ha accounted for $3 \%$. It is also being cultivated in North Indian states as 
temperate crop. In terms of production of grapes also, Maharashtra (21.6 Lakh tones) leads the country with $84 \%$ share to total production, followed by Karnataka with $17 \%$ (3.24 LT), and Tamil Nadu with $3 \%$ (2800 T). In terms of productivity, Maharashtra rank first (24 tons per ha) followed by Andhra Pradesh (20.8 tons per ha) and Tamil Nadu (16.8 tons per ha) among grape producing states in India (Indian Horticulture Database, 2014).

In Tamil Nadu, Theni district accounted for a major share of $78 \%$ of grape area under cultivation (1886.7 ha) followed by Coimbatore with 9\% (214.3 ha), Dindugul with $8 \%$ (197.0 ha) and Krishnagiri with 2\% (56.3 ha). In terms of production, Theni district accounted for $76 \%$ per cent share in the state's total production of grape $(29338 \mathrm{~T})$, followed by Coimbatore district, $11 \%$ (4110 T) and Dindugul district $8 \%(3246 \mathrm{~T})$. However, Coimbatore district ranks first in terms of productivity (19.1 tons per ha) followed by Dindugul district with 16.9 tons per ha.

India exported about 1.60 lakh tons of grapes during the year 2013-14 with a total foreign exchange of Rs.143,707 lakhs. Grape is mainly exported to the Netherlands (29\%), Bangladesh (19\%), Russia (15\%), UK (10\%) and UAE (7\%) which shows that grape is one of the potential fruit crop earning foreign exchange. The quantum of export increased from 94860 tons from 2011-12 to 1.60 lakh tons during 2013-14 (Table 1).

Past studies in Tamil Nadu reveals that over use of pesticide due to disease infestation such as downy mildew and powdery mildew, pest infestation such as flea beetle and high fluctuating price (Ramanan, 2012) were the major constraints in grape cultivation. High initial investment for establishing grapevine orchard (Sumathi, 1992), lack of remunerative price for grapes (Vairam, 2013) were the other issues in grape cultivation. Even then, grapes are cultivated to be the one of the major fruit crop in Tamil Nadu due to its demand by consumer as a table fruit.

In this context, the present study was attempted with following specific objectives. (i) to assess the economics of grapes cultivation in Coimbatore district, (ii) to find out the financial feasibility of establishing grapes vineyard, and (iii) to analyze the constraints in grape cultivation and to suggest suitable measures for promotion of grapes in Tamil Nadu.

\section{Materials and Methods}

Purposive and random sampling was employed for selection of sample district, block and respondents. The total area under grapes in Tamil Nadu for the triennium ending 2013 was 2434 ha. Theni district rank first in terms of area (1886 ha) followed by Coimbatore district (214 ha) and Dindugul district (197 ha). Where as in terms of productivity, Coimbatore rank first $(19.1 \mathrm{t} / \mathrm{ha})$ followed by Dindugul (16.9 t/ha) and Theni (15.6 t/ha) district (Season and Crop Report, Various issues). Hence, Coimbatore district was purposively selected for the present study. Thondamuthur block in Coimbatore was purposively selected for the present study. In Thondamuthur block, 30 grape growers were randomly selected for the study. Hence, the total sample size was 30 .

To analyze the trend in area, production and productivity of grapes in Tamil Nadu, Compound growth rate was employed. The data on area, production, and yield was collected for the years from 2004 to 2014 .

$\mathrm{CGR}=($ Anti $\log$ of $b-1) \times 100$

Cost of production of grapes was estimated 
using the fixed cost and variable cost approach. Total Cost $(\mathrm{TC})=$ Fixed Cost $(\mathrm{FC})$ +Variable Cost (VC), FC includes annual establishment cost of grape vineyard also. Cost of Production (Rs. $/ \mathrm{Kg}$ ) = TC/Yield.

Cobb-Douglas production function was employed to analyze the efficiency of the inputs, taking yield as dependent variable. The model is as follows

$\log \mathrm{Y}=\log \mathrm{a}+\mathrm{b}_{1} \ln \mathrm{X} 1+\mathrm{b}_{2} \ln \mathrm{X} 2+\mathrm{b}_{3} \ln \mathrm{X} 3+$ $b_{4} \ln X 4+b_{5} \ln X 5+b_{6} \ln X 6+b_{7} \ln X 7$

Where,

$\mathrm{Y}=$ Yield ( $\mathrm{Kg} / \mathrm{ha})$,

$\mathrm{X} 1=$ Age of vine yard (Years),

$\mathrm{X} 2=$ Farm yard manure $(\mathrm{Kg} / \mathrm{ha})$,

X3 = Labor (Man days / ha),

$\mathrm{X} 4=$ Cost of plant protection chemical (Rs. / ha),

$\mathrm{X} 5=\operatorname{Nitrogen}(\mathrm{Kg} / \mathrm{ha})$,

$\mathrm{X} 6=$ Phosphorus (Kg / ha) and

$\mathrm{X} 7=$ Potash $(\mathrm{Kg} / \mathrm{ha})$ as independent variable

To analyze the economic feasibility of establishing grapevine orchard, Net Present Worth, Benefit-Cost Ratio and Internal Rate of Return was employed.

$N P V=\sum_{T=1}^{n} \frac{B_{\mathrm{t}}-C_{\mathrm{t}}}{(1+I)^{i}}$

Present worth of net benefit of a project is discounted at opportunity cost of capital (12 $\%)$.

$B-C$ Ratio $=\frac{\sum_{\mathrm{t}=\mathrm{i}}^{\mathrm{n}} \frac{\mathrm{Bt}}{(1+\mathrm{r})^{\mathrm{n}}}}{\sum_{\mathrm{t}=\mathrm{t}}^{\mathrm{n}} \frac{\mathrm{Ct}}{\left.(1+\mathrm{r})^{\mathrm{n}}\right)^{\mathrm{n}}}}$

It measures the ratio of discounted cash inflow (Benefit) and discounted cash outflows (Costs)

$I R R=\left(\begin{array}{c}\text { Lower } \\ \text { discound } \\ \text { Rate }\end{array}\right)+\left(\begin{array}{c}\text { Diff erence } \\ \text { between tow } \\ \text { discound rate }\end{array}\right) *\left(\begin{array}{c}\text { present worth } \\ \text { of the cash flown at the } \\ \text { lower discountrate } \\ \text { Absoiute difference } \\ \text { between the present wrorth } \\ \text { of the cash flow } \\ \text { at the twro twro discount rate }\end{array}\right)$
Internal Rate of return is the rate of return which equates discount benefit with discounted cost. It should be more than the opportunity cost of capital.

Simple percentage analysis was employed to analyze the constraints in production and marketing of grapes.

\section{Results and Discussion}

Grape is being cultivated since 1950's in Coimbatore district and farmers in the early period grown it as a traditional crop. The most important variety grown in Thondamuthur block is Muscat Hamburg (local name is Panner grapes). The vines are raised on stacking (pandal) system.

General characters of sample farmers such as size of the family, literacy level and occupation are presented in table 2. Majority (37\%) of them happened to be middle aged with the mean age of 53.17 years and nearly $70 \%$ of them had secondary education, which helps them to understand modern cultivation methods. Average farming experience was 31 years with experience in grape cultivation was around 24 years. Average family size of the respondents was 4.9 .

The major crops grown in the sample farms are grapes $(41 \%)$, coconut $(15 \%)$, banana $(13 \%)$, and vegetable like onion $(14 \%)$, and other crops (17\%). Of which grapes accounted for $41 \%$ to the total area under cultivation which indicates grape is major crop grown by the sample farmers.

The landholding pattern of the sample farmers are presented in table 3 . It could be inferred from the table that about 40 per cent of the sample respondents are semi medium farmers and 23 per cent of farmers are medium farmers and 6.7 per cent of them are large farmers which indicated $70 \%$ of sample 
farmer were belong to semi medium to large farm size category. Hence, it is inferred that sample grape growers falling under are medium size to large sized farmers and average landholding was 3.81 ha among sample farmer. Moreover, 30 per cent farmers fall under small sized category.

\section{Trend in area, production and productivity of grapes in Tamil Nadu}

To analyze the trend in area, productions, productivity of grapes for 10 years (20042014) in Tamil Nadu, were collected and analyzed using compound growth rate. The result shows (Table 4) that area under grape cultivation is decreasing over a decade with a growth rate of $-1.17 \%$, Similarly, production of grapes declined with $-10.16 \%$ and productivity declined with $-9.55 \%$ for the same period.

It is evident from the result that area, production and productivity of grapes in Tamil Nadu shown decline trend for the last 10 years due to various reasons. However, productivity declined at an alarming rate during the last decade.

\section{Economics of grape production}

It could be observed from the table 5 that per ha establishment cost of grapevine orchard was worked out to Rs. 4, 24,593. Of which, stone and wire mess accounted for a major share $(70 \%)$ followed by farmyard manure and fertilizer (12\%). Hence, the annual establishment cost worked out to Rs. 42, 460 per ha assuming 10 years of life period of grapevine orchard.

The economics of grapevine orchard is presented in table 6 . It could be observed that the total variable cost of cultivation /ha was Rs. 2.92 lakhs. Of which labour cost alone accounted for about 29 per cent to the total cost, followed by cost of pesticide (12 per cent). Labour cost alone accounted for about 32 per cent of the total cost. It is concluded that cost of labour accounted for the major share to the total variable cost.

Fixed cost accounted for $35 \%$ to the total cost. The total cost of cultivation was worked out to be 4.49 lakh. On an average, yield realized was $24,368 \mathrm{~kg} /$ ha and the average price was Rs.27/kg. Cost of production was worked out to Rs. $18.5 / \mathrm{kg}$ which is lesser than the average price realized and hence, the farmers is able to get a positive net return of Rs.2.13 lakh per ha.

\section{Determinants of grape cultivation}

To evaluate the factors influencing grape cultivation and also to examine their relative influence, Cobb-Douglas production function was fitted. The estimated values of the regression coefficients were tested for statistical significance with the help of ' $t$ ' test and the significance of the equation was tested by ' $F$ ' test for $\mathrm{R}^{2}$. The results are shown in table 7. The co-efficient of multiple determination $\left(\mathrm{R}^{2}\right)$ value was 0.7539 , which indicated that approximately 75 per cent of the variation in the dependent variable was explained by the relevant independent variables selected for the study.

Age of vine yard was found to be positively significant at one per cent level of probability, which indicated that an increase in age of vine yard by one per cent, ceteris paribus, would increase yield by 0.27 per cent level. Farmyard manure was found to be positively significant at five per cent level of probability, indicating one per cent increase in use of farmyard manure would increase the yield by 0.9 per cent.

Application of phosphorus was also positively significant at five per cent level of 
probability, indicating one per cent increase in use of phosphorus would increase the yield by 0.15 per cent. It is concluded that age of vine yard, application of farm yard manure, and phosphorus are positively influence the yield of grape.

Table.1 Export of grapes in India

\begin{tabular}{|c|c|c|c|}
\hline Year & $\begin{array}{c}\text { Export } \\
\text { Quantity (MT) }\end{array}$ & Percentage Change & $\begin{array}{c}\text { Value of export } \\
\text { (Rs. in lakhs) }\end{array}$ \\
\hline $2011-12$ & 94860 & - & 51676 \\
\hline $2012-13$ & 140967 & 48.6 & 98204 \\
\hline $2013-14$ & 160256 & 13.68 & 143707 \\
\hline
\end{tabular}

(Source: APEDA, January 2015).

Table. 2 General characteristics of sample respondents

\begin{tabular}{|c|c|c|c|c|}
\hline S.No & Particulars & Criteria & No. of farmers & Average \\
\hline \multirow{4}{*}{1} & \multirow{4}{*}{ Age (years) } & $30-40$ & $4(13)$ & \multirow{4}{*}{53.17} \\
\hline & & $41-50$ & $11(37)$ & \\
\hline & & $51-60$ & $8(27)$ & \\
\hline & & $>60$ & $7(23)$ & \\
\hline \multirow{4}{*}{2} & \multirow{4}{*}{ Education } & Illiterate & - & \\
\hline & & Primary & $2(7)$ & \\
\hline & & Hr. Sec & $21(70)$ & \\
\hline & & Graduate & $7(23)$ & \\
\hline \multirow{4}{*}{3} & \multirow{4}{*}{$\begin{array}{l}\text { Farming experience } \\
\text { (years) }\end{array}$} & $11-20$ & $8(27)$ & \multirow{4}{*}{30.47} \\
\hline & & $21-30$ & $13(43)$ & \\
\hline & & $31-40$ & $5(17)$ & \\
\hline & & $41-50$ & $4(13)$ & \\
\hline \multirow{4}{*}{4} & \multirow{4}{*}{$\begin{array}{l}\text { Experience grapes } \\
\text { cultivation (years) }\end{array}$} & $1-10$ & $3(10)$ & \multirow{4}{*}{23.8} \\
\hline & & $11-20$ & $11(37)$ & \\
\hline & & $21-30$ & $11(37)$ & \\
\hline & & $>30$ & $5(16)$ & \\
\hline
\end{tabular}

(Figures in parentheses indicate percentage to total); $\mathrm{N}=30$

Table.3 Land holding pattern

\begin{tabular}{|c|l|c|c|}
\hline S.No & Category of Farmers & $\begin{array}{c}\text { Number of } \\
\text { Farmers (N=30) }\end{array}$ & Mean Area \\
\hline 1 & Marginal (<1 ha) & $2(6.7)$ & 0.81 \\
\hline 2 & Small (1-2 ha) & $7(23.3)$ & 1.62 \\
\hline 3 & Semi Medium (2-4 ha) & $12(40.0)$ & 2.87 \\
\hline 4 & Medium (4-10 ha) & $7(23.3)$ & 5.40 \\
\hline 5 & Large (>10 ha) & $2(6.7)$ & 13.16 \\
\hline
\end{tabular}

(Figures in parentheses indicate percentage to total)

Table.4 Trend in area, production and productivity of grapes in Tamil Nadu*

\begin{tabular}{|c|l|c|}
\hline S.No & \multicolumn{1}{|c|}{ Particulars } & Compound Growth Rate (\%) \\
\hline 1 & Area & -1.17 \\
\hline 2 & Production & -10.16 \\
\hline 3 & Productivity & -9.55 \\
\hline
\end{tabular}

(Source: Season and Crop Report, Various Issues) From 2004 to 2014. 
Table.5 Establishment cost of grapevine orchard

\begin{tabular}{|c|l|c|c|}
\hline \multicolumn{1}{|c|}{ Particulars } & Value (Rs.) & Percentage to total \\
\hline S.No & \multicolumn{1}{|c|}{ ha) } \\
\hline 1 & Land preparation and digging & 18278 & 4.00 \\
\hline 2 & Stone & 256880 & 61.00 \\
\hline 3 & Wire mess & 39520 & 9.00 \\
\hline 4 & Cuttings (seedlings) & 29640 & 7.00 \\
\hline 5 & Planting & 1976 & 1.00 \\
\hline 6 & Inter cultural operations & 22724 & 5.00 \\
\hline 7 & FYM and Fertilizers & 49400 & 12.00 \\
\hline 8 & Pesticides & 6175 & 1.00 \\
\hline & Total Establishment Cost & $4,24,593$ & 100.00 \\
\hline & Annual Establishment Cost & 42,460 & \\
\hline
\end{tabular}

Table.6 Economics of cultivation of grape (Panner Variety)

\begin{tabular}{|c|c|c|c|}
\hline $\mathbf{S N o}$ & Particularc & Value $\left(\mathbf{P}_{\mathrm{c}}\right)$ & $\begin{array}{r}\text { (Rs.) } \\
\text { Porcentageto }\end{array}$ \\
\hline I & Operational Cost & & \\
\hline 1 & Labour (including family labour) & $1,30,330$ & 28.97 \\
\hline 2 & Machine power & 43,720 & 9.72 \\
\hline 3 & Organic manures & 23,057 & 5.12 \\
\hline 4 & Inorganic fertilizers & 19,990 & 4.44 \\
\hline 5 & Plant protection chemicals & 54,285 & 12.06 \\
\hline \multirow[t]{2}{*}{6} & Interest on working capital & 21,555 & 4.79 \\
\hline & Total Operational Cost & $2,92,940$ & 65.12 \\
\hline II & Fixed Cost & & \\
\hline 7 & Annual establishment cost & 42,459 & 9.43 \\
\hline 8 & Depreciation on fixed capital @ $12 \%$ & 42,929 & 9.54 \\
\hline 9 & Land revenue & 60 & 0.01 \\
\hline 10 & Interest on fixed capital @ $12 \%$ & 34,343 & 7.63 \\
\hline \multirow[t]{2}{*}{11} & Rental value of owned land & 37,050 & 8.23 \\
\hline & Total Fixed Cost & $1,56,842$ & 34.87 \\
\hline III & Total Cost & $\mathbf{4 , 4 9 , 7 8 2}$ & 100 \\
\hline \multirow[t]{4}{*}{ IV } & Yield (Kg) & 24,368 & \\
\hline & Price $(\mathrm{Rs} / \mathrm{Kg})$ & 27 & \\
\hline & Gross Return & $6,62,819$ & \\
\hline & Net Return & $2,13,038$ & \\
\hline $\mathbf{V}$ & Cost of Production (Rs/Kg) & 18.45 & \\
\hline
\end{tabular}

Percentage is calculated to the total cost

Table.7 Results of Cobb-Douglas production function analysis determinants of grape cultivation

\begin{tabular}{|l|l|c|c|c|}
\hline S.No & \multicolumn{1}{|c|}{ Explanatory variables } & Coefficient & Standard error & t-ratio \\
\hline 1 & Constant & 0.4484 & 3.8105 & 0.1176 \\
\hline 2 & Age of vine yard (Years) & $0.2793^{* * *}$ & 0.0981 & 2.8474 \\
\hline 3 & Farmyard Manure (Kg/ha) & $0.9537 * *$ & 0.3905 & 2.4419 \\
\hline 4 & labour (Man days/ha) & -0.1800 & 0.1552 & -1.1595 \\
\hline 5 & Plant Protection Chemicals (Rs/ha) & -0.0026 & 0.0392 & -0.0679 \\
\hline 6 & $\mathrm{~N}(\mathrm{Kg} / \mathrm{ha})$ & 0.0336 & 0.0527 & 0.6366 \\
\hline 7 & $\mathrm{P}(\mathrm{Kg} / \mathrm{ha})$ & $0.1545^{* *}$ & 0.0707 & 2.1828 \\
\hline 8 & $\mathrm{~K}(\mathrm{Kg} / \mathrm{ha})$ & 0.0259 & 0.0354 & 0.7309 \\
\hline
\end{tabular}

Significant at one per cent level, ${ }^{* *}$ Significant at five per cent level. 
Table.8 Net present worth, benefit cost ratio and internal rate of return

\begin{tabular}{|c|c|c|c|c|c|c|c|c|}
\hline Years & Cost & Return & $\begin{array}{c}\text { Net } \\
\text { Benefit }\end{array}$ & $\begin{array}{c}\text { Discount } \\
\text { Factor 12\% }\end{array}$ & $\begin{array}{c}\text { Discounted } \\
\text { Cost @ 12\% }\end{array}$ & $\begin{array}{c}\text { Discounted } \\
\text { Benefit } \\
@ \mathbf{1 2 \%}\end{array}$ & $\begin{array}{c}\text { Discount } \\
\text { factor } \\
\mathbf{3 5 \%}\end{array}$ & $\begin{array}{c}\text { Discount } \\
\text { Benefit @ } \\
\mathbf{3 5 \%}\end{array}$ \\
\hline 1 & 434790 & 0 & -434790 & 0.8928 & 388206 & 0 & 0.7407 & -322067 \\
\hline 2 & 108491 & 200000 & 91508 & 0.7971 & 86488 & 159438 & 0.5486 & 50210 \\
\hline 3 & 120546 & 280000 & 159453 & 0.7117 & 85802 & 199298 & 0.4064 & 64808 \\
\hline 4 & 132600 & 295000 & 162399 & 0.6355 & 84270 & 187477 & 0.3010 & 48893 \\
\hline 5 & 144655 & 300000 & 155344 & 0.5674 & 82081 & 170228 & 0.2230 & 34643 \\
\hline 6 & 166809 & 345000 & 178190 & 0.5066 & 84510 & 174787 & 0.1651 & 29436 \\
\hline 7 & 281092 & 402819 & 121726 & 0.4523 & 127151 & 182214 & 0.1223 & 14895 \\
\hline 8 & 204655 & 460000 & 255344 & 0.4038 & 82656 & 185786 & 0.0906 & 23144 \\
\hline 9 & 205670 & 500056 & 294385 & 0.3606 & 74166 & 180325 & 0.0671 & 19765 \\
\hline 10 & 246950 & 602819 & 355868 & 0.3219 & 79511 & 194091 & 0.0497 & 17699 \\
\hline Total & 2046264 & 3385694 & 1339430 & & 1174847 & 1633649 & & -18569 \\
\hline
\end{tabular}

Table.9 Constraints faced by grape growers

\begin{tabular}{|c|l|c|c|}
\hline S.No & \multicolumn{1}{|c|}{ Problems } & $\begin{array}{c}\text { No. of Farmers } \\
(\mathbf{N = 3 0})\end{array}$ & $\begin{array}{c}\text { Reported } \\
\text { Percentage to Total }\end{array}$ \\
\hline 1 & Disease Infestation & 30 & 100 \\
\hline 2 & Incidence of pests & 19 & 63.3 \\
\hline 3 & Scarcity of labour & 20 & 66.7 \\
\hline 4 & Water scarcity & 20 & 66.7 \\
\hline 5 & $\begin{array}{l}\text { Non availability of } \\
\text { quality cuttings }\end{array}$ & 8 & 26.7 \\
\hline 6 & Price fluctuation & 30 & 100 \\
\hline 7 & Lack of Price information & 21 & 70 \\
\hline
\end{tabular}

\section{Financial feasibility- analysis}

To analyze the financial feasibility of establishment of grape vineyard, discounted measures were employed and the results are presented in the table 8 .

\section{Net Present Worth (NPW)}

The Net Present Worth of grape enterprise was worked out to Rs. 4.58 lakhs per hectare which is positive value at the discount rate of 12 per cent as opportunity cost of capital with 10 years of life period. The positive net present worth indicated that the grape cultivation is found to be financially feasible.

\section{Benefit-cost ratio}

The benefit-cost ratio was worked out to 1.39:1, which indicate that for every one rupee invested in the grape enterprise, the benefit received would be Rs.1.39.

This measure also indicated the financial feasibility of the investment.

\section{Internal rate of return}

The internal rate of return of grape enterprise is presented in table 8 .

It could be observed that the internal rate of return of grape enterprise was worked out to 
33 per cent indicating the higher earning power of the enterprise.

Since Net Present Worth, Benefit Cost Ratio, and Internal Rate of Return indicated that grape vine yard enterprises is found to be financially feasible.

\section{Marketing of grapes}

The sample grape growers sold fresh grapes to local wholesale traders only. Farmers contact the local traders if the grape was matured to harvest. Local wholesale traders fix the rate for produce based on market forces and collect produces at farm gate level.

Farmer $\rightarrow$ Local Wholesale Trader $\rightarrow$ Retailer $\rightarrow$ Consumer

\section{Constraints faced by grape growers}

The constraints faced by grape farmers in production and marketing were analyzed and presented in Table 9.The most important constraint was disease Infestation (downey mildew and powdery mildew) which reported by all the sample farmers followed by scarcity of labour $(66.7 \%)$ and water is $66 \%$ and incidence of pests (flea beetle) $63.3 \%$ in production of grapes.

Price fluctuation was major problem in marketing followed by lack of price information in marketing of grapes.

Based on the result of the study, it is concluded that average farm size was 3.81 ha. Most of sample farmer are medium category farmers. The establishment cost of grapes was about Rs. 4, 24 lakh per ha. Labour cost alone accounted for 29 per cent of total cost, which shows grape is labour intensive crop. Net income from grape cultivation was high which is about Rs. 2.55 lakhs per ha. Area, production and productivity of grapes showed a declining trend over a period of 10 years in Tamil Nadu.

Age of vine yard, application of farmyard manure and phosphorus are the variable has positively influence the yield of grapes. Grape enterprise was found to financially feasible and net return was high.

In grape cultivation, powdery and downey mildew is a major disease and hence, farmer use more of inorganic chemicals (39 times per year) which will affect the marketing of produce. Lack of price information was also major constrain faced by the farmers

Hence, it is suggested that research may be formulated to control the disease in an effective manner. so as to retain the area under grapes being a potential crop and, the grape grower association may provide the price information to the growers instantly and credit support through subsidy by the department of horticulture may given to encourage the farmers to promote grape production.

\section{References}

Vairam. R, B. Muniyandi,. An Economic Analysis of the Production and Marketing of Grape Cultivation in Theni District, Tamil Nadu, International Journal of Research in Commerce, Economics and Management. 2013; 3(9): pp 14 - 18,

Babybowna, R. and P. Veerachamy, Cost of Production of Grape in Dindigul District, Tamil Nadu, Language in India. 2012; 12(5).

Ramanan, G, Cost of Production and Capital Productivity of Grape Cultivation in Tamilnadu, India, Indian Streams Research Journal. 2012; 2(1): pp 1-4,

Gade A. D., Gaikwad S. B. and Gaikwad N. S., Trends in Production and Exports of Grapes in India, Indian Streams 
Research Journal. 2014; 4(2).

National Research Centre for Grapes, Indian Council of Agricultural Research, Government of India, Pune. 2006.

Indian Horticulture Database, Ministry of Agriculture, Government of India, Gurgaon.

Season and Crop Report of Tamil Nadu,
Department of Economics and Statistics, Government of Tamil Nadu, Chennai, various issues. 2014.

Sumathi, P., An Economic Analysis of Production and Marketing of Grapes in Coimbatore District, M.Sc. (Agri) Unpublished thesis, TNAU, Coimbatore. 1992.

\section{How to cite this article:}

Appasmandri, S., M. Anjugam, M. Sathaiah and Muthuraja, B. 2017. Production and Profitability Analysis of Grapevine Orchard in Coimbatore, Tamil Nadu, India. Int.J.Curr.Microbiol.App.Sci. 6(7): 2172-2180. doi: https://doi.org/10.20546/ijcmas.2017.607.255 